\title{
The role of KiSS-1 in the regulation of puberty in higher primates
}

\author{
Tony M Plant \\ Department of Cell Biology and Physiology and Obstetrics, Gynecology and Reproductive Sciences, University of Pittsburgh School of Medicine, 3550 \\ Terrace Street, Rm 828 Scaife Hall, Pittsburgh, Pennsylvania 15261, USA
}

(Correspondence should be addressed to T M Plant; Email: plant1@pitt.edu)

\begin{abstract}
Puberty in higher primates is triggered by resurgence in the pulsatile secretion of hypothalamic GnRH after a hiatus in the robust release of this hypophysiotropic signal during childhood and juvenile development. Interestingly, the prepubertal decline in GnRH release is not associated with a marked reduction in the expression of either the gene that codes for $\mathrm{GnRH}(\mathrm{GnRH}-1)$ or the decapeptide itself, and the network of GnRH neurons in the hypothalamus of the juvenile may by activated prematurely and with surprising ease by intermittent neurochemical stimulation with $N$-methyl-D-aspartate (NMDA), a glutamate receptor agonist. KiSS-1, a gene that encodes for kisspeptin-121, which is proteolytically cleaved to a 54 amino acid peptide, metastin, was initially studied in the context of tumor suppression. In 2003, however, inactivating mutations in the metastin receptor, GPR54, were reported to be associated with hypogonadotropic hypogonadism and absent puberty in man. Subsequent studies in the rhesus monkey have shown that GPR 54 and KiSS-1 are expressed in the mediobasal hypothalamus (MBH), KiSS-1 expression in the MBH increases at the time of the pubertal resurgence in GnRH release and pulsatile, but not continuous, i.v. administration of metastin 45-54 in the juvenile male monkey elicits sustained GnRH release precociously. The significance of these findings in the context of the initiation of the onset of puberty is discussed.
\end{abstract}

European Journal of Endocrinology 155 S11-S16

\section{Introduction}

The gene, KiSS-1, was cloned in 1996 at the Pennsylvania State College of Medicine by a group interested in the suppression of metastasis (1). Apparently, the gene was named so because this Institution is located in Hershey, Pennsylvania, in the United States, a town famous for its confectionary products, in particular Hershey Chocolate Kisses (D R Welch, personal communication, 2005). KiSS - 1 codes for a 121 amino acid protein, kisspeptin121 , which is proteolytically cleaved in man to a 54 amino acid peptide, metastin (2-4). The name metastin derives from the ability of the peptide to suppress proliferation in cell lines derived from human melanomas and breast carcinomas $(1,5)$. The receptor mediating the action of metastin was recognized in 2001 to be GPR 54, a G-protein-coupled receptor (2-4), which had been identified 2 years earlier as an 'orphan receptor' in rat (6). GPR 54 is coupled to the Gq subclass of G-proteins and activation of the receptor promotes phosphatidylinositol turnover, calcium mobilization,

This paper was presented at the 4th Ferring Pharmaceuticals International Paediatric Endocrinology Symposium, Paris (2006). Ferring Pharmaceuticals has supported the publication of these proceedings. and signaling in pathways involving MAP kinases. Signal transduction in the metastin-GPR54 pathway has recently been reviewed (7).

Interestingly, a neuroendocrine role of GPR 54 signaling only emerged in 2003, when it was reported that several members of two large consanguineous families presenting with hypogonadotropic hypogonadism and absent puberty were found to carry homozygous mutations for GPR54 $(8,9)$. In one other subject bearing a compound heterozygote mutation of GPR54, administration of a pulsatile regimen of GnRH reversed the hypogonadotropism (9), indicating a hypothalamic locus for the deficit associated with this genetic disorder. One of these signal papers (8) concluded with the statement 'a new chapter may thus be opened in the physiology of the gonadotropic axis', and the other (9) with the notion 'GPR54 is a key regulator of the biology of puberty'. The present review examines the latter, more circumspect, and perhaps the more intriguing suggestion.

\section{Puberty and its neuroendocrine determinants}

Puberty in man is a period of development that results from the expression of two physiological processes, 
namely adrenarche and gonadarche (10). Adrenarche, the increase in adrenal androgen secretion typically observed at approximately 8-9.5 years of age in girls and boys, is only observed in man and the great apes (11). Of the two processes, only gonadarche is critical to the onset of fertility and, from a biological perspective, may therefore be considered fundamental to the process of puberty (12). Adrenarche, on the other hand, may be viewed as a temporally related corollary of puberty. Throughout the present review, gonadarche and puberty will be used interchangeably although this is not strictly correct in the case of human development.

Gonadarche is triggered by resurgence in the pulsatile pattern of hypothalamic GnRH secretion after a hiatus or dampening of this neuroendocrine activity during childhood and the juvenile years that intervene between infancy and puberty $(11,12)$. The diminished activity in the hypothalamic-pituitary axis during the greater part of prepubertal development guarantees the relative quiescence of both the male and female gonad of the child and the juvenile. Interestingly, the network of hypothalamic GnRH neurons that discharges pulses of the decapeptide during infancy and puberty appears to be held in a state of functional readiness during the intervening period of childhood and juvenile development. In the monkey, hypothalamic levels of mRNA coding for GnRH and the content of the peptide in this region of the brain during juvenile development when GnRH pulsatile release is restrained, is similar to that during infancy and puberty when pulsatile GnRH release is robust (13-16). Moreover, a pattern of $\mathrm{GnRH}$ secretion similar to that of the pubertal state may be precociously elicited with remarkable ease from the hypothalamus of the juvenile by applying a repetitive intermittent chemical stimulation with the glutamate-receptor agonist, NMDA $(17,18)$. Thus, it may be concluded that, the molecular and cellular machinery for generating an adult hypophysiotropic drive to the gonadotrope is extant throughout childhood and juvenile development and the signal responsible for the initiation of gonadarche must originate upstream from the hypothalamic network of GnRH neurons. The upregulated state of the GnRH neuron in the hypothalamus of the juvenile is an interesting contrast to the pituitary gonadotrope in which, at the same stage of development, expression of the gonadotropin subunits is minimal and the cell is hyporesponsive to stimulation by GnRH ((19), Winters and Plant, unpublished observations).

As implied, the ability of the hypothalamus to generate a pulsatile $\mathrm{GnRH}$ discharge originates well before the onset of puberty, actually during fetal development at the time when these hypothalamic neurons complete their migration from the olfactory bulb (20). Although fetal GnRH release is suppressed during the latter stages of gestation, probably by the rising levels of fetoplacental steroids, following birth and the loss of the inhibitory action of these hormones, GnRH pulsatility is expressed in a robust fashion (11). Thus, the ontogeny of GnRH release during postnatal development in higher primates is characterized by an 'on-off-on' pattern. Since the pituitary-gonadal axis in both the male and the female is capable of responding to pulsatile GnRH stimulation well before the onset of puberty (11), the neural mechanism that times the initiation of gonadarche in primates may be viewed as one that regulates a delay (rather than onset) in this developmental process (21).

\section{The role of KiSS-1 in dictating the on-off-on pattern of GnRH drive to the pituitary-gonadal axis during postnatal development}

To date, studies on the role of KiSS-1 in dictating the postnatal ontogeny of the hypophysiotropic drive to the pituitary-gonadal axis of the primate have focused primarily on the 'off-on' transition that occurs at the initiation of puberty. Following the initial observations in man that inactivating mutations of GPR 54 were associated with hypogonadotropic hypogonadism and absent puberty, it was reasoned that if an increase in metastin-GPR 54 signaling was the proximate trigger for increased pulsatile GnRH release at this stage of development, then the following conditions should apply: (i) KiSS-1 and GPR 54 should be expressed in the medial basal hypothalamus (MBH), the area of the primate brain containing the majority of neuroendocrine GnRH neurons (22); (ii) an increase in GPR 54 signaling should occur in association with the onset of puberty; and (iii) a premature increase in metastin tone in the MBH during juvenile development should elicit a precocious pubertal pattern of $\mathrm{GnRH}$ release. Using the rhesus monkey (Macaca mulatta), a species of higher primate in which puberty occurs at 3-4 years of age (11), and in collaboration with the laboratories of W R Crowley and S R Ojeda, all three of these conditions have been confirmed. Hybridization histochemistry demonstrated that KiSS-1 is discretely expressed in neurons in the region of the arcuate (infundibular) nucleus of the MBH (Fig. 1). Expression of the receptor was also observed in this hypothalamic region, although the pattern of expression was more generalized than that of the ligand (23). Real-time PCR revealed that hypothalamic KiSS-1 expression increased at the time of pubertal resurgence in GnRH release in both male and female, while an increase in GPR 54 expression during this developmental transition was observed only in the female (23). At present, it is not known whether this male/female difference represents a consequence of testicular-dependent programming of hypothalamic function during fetal development. This is because our male monkeys were studied in the agonadal condition (castration between 16 and 21 months of age), while the females were ovarian intact. Thus, the peripubertal sex differences that have been observed in the developmental expression of GPR 54 in the monkey may simply be related to the difference in hormonal status of the animals 

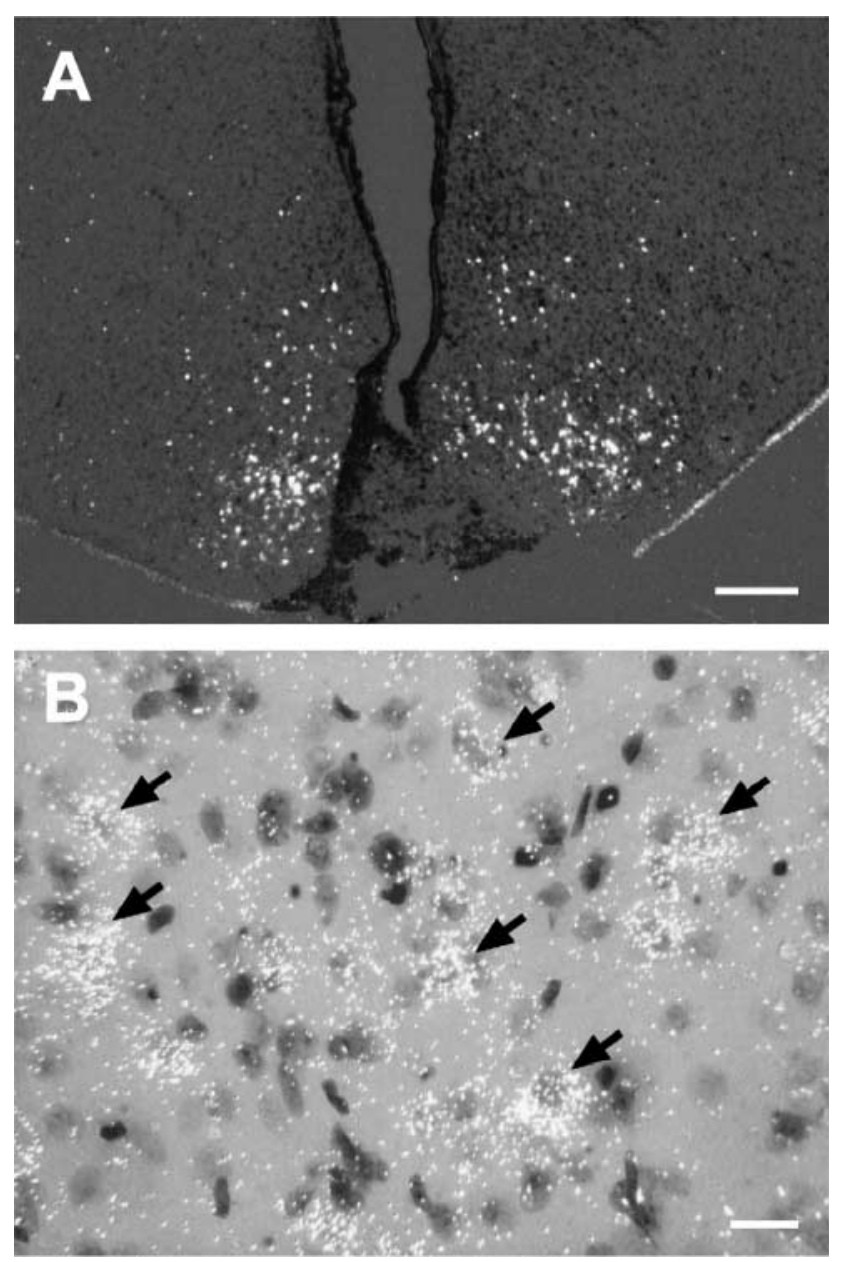

Figure 1 Selective expression of KiSS-1 mRNA in neurons of the arcuate nucleus of the female monkey. (A) Low magnification view. $\mathrm{Bar}=400 \mu \mathrm{m}$, (B) merged bright- and dark-field higher magnification image showing the presence of KiSS-1 mRNA transcripts in neurons of the arcuate nucleus (arrows). Bar $=20 \mu \mathrm{m}$. Reprinted from Ref. (23).

studied. In this regard, KiSS-1 expression is modulated by both testicular and ovarian steroids (24). Finally, administration of brief i.v. infusions of human metastin $45-54$ ( $2 \mu \mathrm{g} /$ monkey over $1 \mathrm{~min})$ every hour, for $48 \mathrm{~h}$, to agonadal juvenile males, 20-24 months of age, but in which pituitary responsiveness to GnRH had been increased by a 'priming' infusion of exogenous $\mathrm{GnRH}$ $(0.15 \mu \mathrm{g} / \mathrm{min}$ for $2 \mathrm{~min}$ every hour), elicited a sustained train of endogenous hypothalamic GnRH discharges, as reflected by the pulsatile pattern of circulating luteinizing hormone (LH) concentrations ((25), Fig. 2). That the site of this action of metastin is hypothalamic was indicated by the finding that metastin-induced LH release was abolished by treatment with acyline, a GnRH-receptor antagonist (25). Since GnRH neurons in the hypothalamus of both the rodent and the primate express GPR 54 mRNA $(26,27)$, it is reasonable to propose that the stimulatory action of metastin on GnRH release represents a direct action on GnRH neurons.

The ability of repetitive hourly activation of hypothalamic GPR54 in the juvenile monkey to elicit robust trains of GnRH discharges without evidence of decrement is reminiscent of the action of NMDA (17), which when administered in a pulsatile manner for several months drives the hypothalamic-pituitary-testicular axis of the juvenile monkey into an adult mode of operation with the onset of episodic testicular testosterone secretion and initiation of spermatogenesis (18). The authors predict that similar chronic, repetitive stimulation of hypothalamic GPR54 in the juvenile monkey would also result in precocious gonadarche, and have previously argued that the role of kisspeptinergic neurons in hypothalamic function may be restricted to that of regulating GnRH release, while that of glutamatergic interneurons may be more promiscuous (28).

In contrast to the ability of pulsatile stimulation with metastin to elicit a sustained hypophysiotropic drive to the gonadotrope in the juvenile monkey, in which endogenous GnRH release is greatly dampened (the 'off' phase of postnatal development), continuous i.v. infusions of metastin 45-54 ranging in dose from 1 to $100 \mu \mathrm{g} / \mathrm{h}$, during this phase of development, failed to sustain GnRH release in the same experimental model (29). Further study is required to determine the significance of the difference in the effectiveness of the hypothalamic actions of these two modes of i.v. metastin 45-54 administration.

Parenthetically, it deserves to be mentioned that the high dose, continuous metastin 45-54 infusion $(100 \mu \mathrm{g} / \mathrm{h})$ to the juvenile monkey, although producing an initial stimulation of GnRH release lasting, approximately, $1-3 \mathrm{~h}$, resulted, after 4 days of uninterrupted exposure, in desensitization of GPR54 ((30), Fig. 3). Metastin 45-54-induced desensitization, however, neither compromised the ability of the GnRH neuronal network to respond to stimulation with the glutamate agonist, NMDA, nor impaired the pituitary's ability to respond to physiologic stimulation with a bolus of synthetic GnRH (30). GPR54 was re-sensitized within $24 \mathrm{~h}$ following termination of the continuous metastin 45-54 infusion. The ability of metastin 45-54 to downregulate GPR54 offers potential new approaches to probe the control of the hypothalamic-pituitary axis and perhaps to the development of therapeutic approaches for the treatment of reproductive disorders (30).

As described earlier, changes in metastin-GPR 54 signaling at the GnRH neuron in the primate hypothalamus during the infantile-juvenile 'on-off' transition are yet to be described. However, based on the report of hypogonadotropism and low-circulating testosterone concentrations at 2 months of age in one infantile boy with a homozygous mutation for GPR 54 (31) it would seem reasonable to propose that GPR 54 


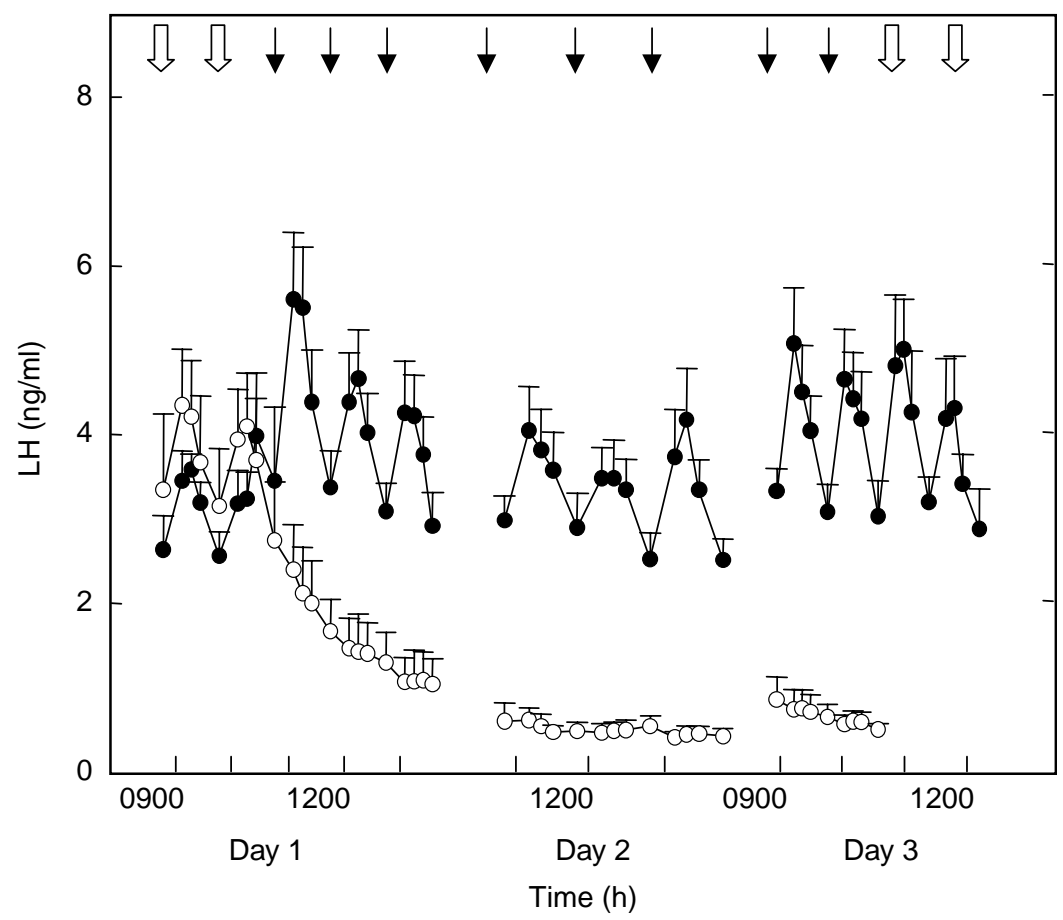

Figure 2 Discharges of luteinizing hormone $(\mathrm{LH})$, as reflected by circulating concentrations of the gonadotropin, during the last two priming pulses of synthetic GnRH (open arrows) on day 1 in agonadal male rhesus monkeys were sustained without decrement by an intermittent i.v. infusion of $2 \mu \mathrm{g}$ metastin $45-54 /$ monkey administered as a 1 min pulse every hour for $48 \mathrm{~h}$ from $1100 \mathrm{~h}$ on day 1 , to $1000 \mathrm{~h}$ on day 3 (solid data points) after withdrawing $\mathrm{GnRH}$ treatment on day 1 , but not during vehicle administration (open data points). Although metastin 45-54 or vehicle was administered every hour, the $\mathrm{LH}$ response was tracked for only two or three pulses each day. The LH response to re-initiation of pulsatile $\mathrm{GnRH}$ priming at $1100 \mathrm{~h}$ on day 3 was monitored after both metastin 45-54 and vehicle treatment, but only shown for the former treatment because of the exaggerated response in the vehicle group. Solid arrows indicate times of pulse infusions of metastin 45-54 that were selected for tracking $\mathrm{LH}$ responses. Open arrows indicate time of $\mathrm{GnRH}$ pulse infusions. Values are mean \pm S.E.M. Reprinted with permission from Ref. (25). signaling in the GnRH neuron is critical for a functional GnRH drive to the pituitary-gonadal axis during infancy, as it is during puberty. This being the case, it is to be anticipated that during the transition from infancy to the juvenile state, expression of KiSS-1 would decline and, therefore, mirror the upregulation in expression of this gene at puberty.

\section{Is GPR 54 therefore a key regulator of the biology of puberty?}

Compelling evidence from studies of several mammalian species is now at hand demonstrating that metastin signaling at GPR 54 represents a critical, and probably obligatory, component of the neuroendocrine control

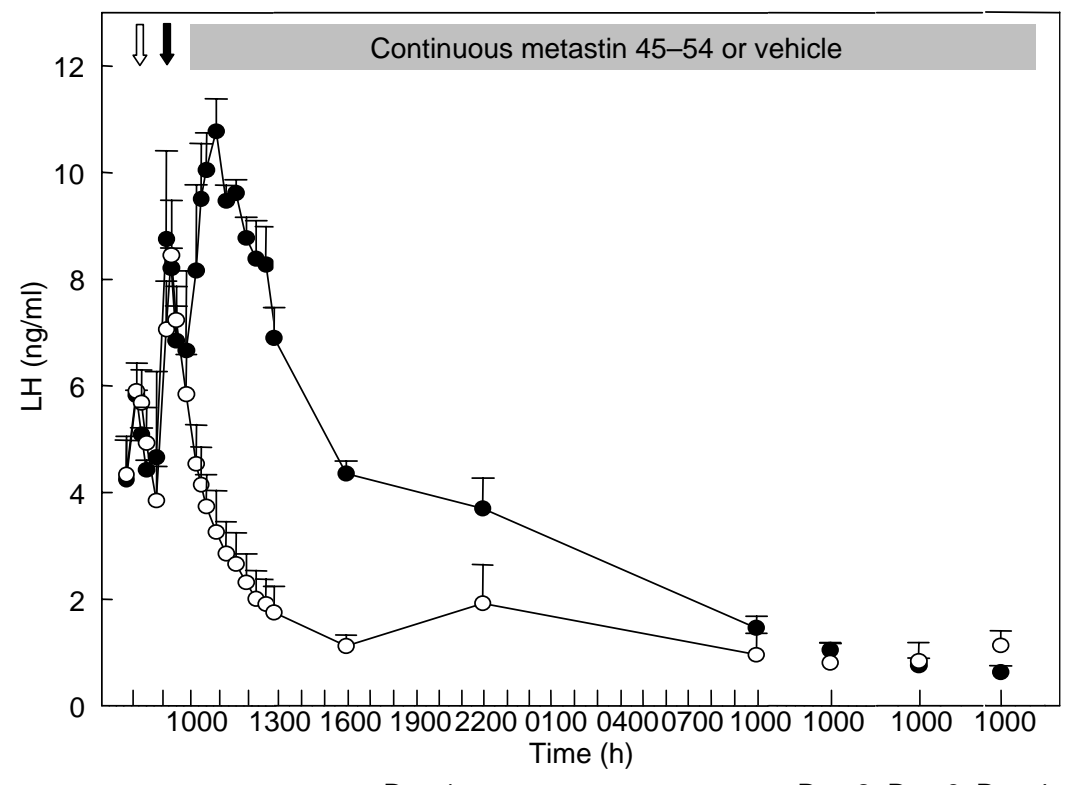

Day 1
Figure 3 Effect of continuous administration of metastin 45-54 on LH release in agonadal juvenile male rhesus monkeys, in which pituitary responsiveness to $\mathrm{GnRH}$ had been previously increased by pulsatile $\mathrm{GnRH}$ treatment. Dark circles represent LH levels (mean \pm S.E.M.) from three monkeys receiving $100 \mu \mathrm{g} / \mathrm{h}$ metastin 45-54 over a $98 \mathrm{~h}$ infusion period (shaded horizontal bar). Open circles represent mean LH levels during vehicle infusion. Administration of metastin $45-54$ or vehicle was initiated at $1000 \mathrm{~h}$ on day 1 . White arrow indicates i.v. administration of last $\mathrm{GnRH}$ priming pulse at $0800 \mathrm{~h}$ on day 1 . Black arrow indicates i.v. administration of single bolus of metastin 45-54 at $0900 \mathrm{~h}$ on day 1 . Reprinted with permission from Ref. (30). 
system regulating GnRH release $(8,9,24,32-35)$, and hence it is reasonable to conclude, as done by Seminara et al. (9) that this membrane receptor is a key regulator of the biology of puberty. However, after three further exciting years of probing the physiology of kisspeptin in the context of the neuroendocrine axis governing reproduction, it is time to rephrase the question with more focus, namely, 'Will GPR54 lead us to a resolution of the fascinating mystery of the timing of puberty?'

\section{Acknowledgements}

The work conducted in the author's laboratory was supported by NIH (HD 13254 and HD 08160).

\section{References}

1 Lee JH, Miele ME, Hicks DJ, Phillips KK, Trent JM, Weissman BE \& Welch DR. KiSS-1, a novel human malignant melanoma metastissuppressor gene. Journal of the National Cancer Institute $1996 \mathbf{8 8}$ 1731-1736.

2 Ohtaki T, Shintani Y, Honda S, Matsumoto H, Hori A, Kanehashi K, Terao Y, Kumano S, Takatsu Y, Masuda Y, Ishibashi Y, Watanabe T, Asada M, Yamada T, Suenaga M, Kitada C, Usuki S, Kurokawa T, Onda H, Nishimura O \& Fujino M. Metastasis suppressor gene KiSS-1 encodes peptide ligand of a G-protein-coupled receptor. Nature 2001 411 613-617.

3 Muir AI, Chamberlain L, Elshourbagy NA, Michalovich D, Moore DJ, Calamari A, Szekeres PG, Sarau HM, Chambers JK, Murdock P, Steplewski K, Shabon U, Miller JE, Middleton SE, Darker JG, Larminie CGC, Wilson S, Bergsma DJ, Emson P, Faull R, Philpott KL \& Harrison DC. AXOR12, a novel human G protein-coupled receptor, activated by the peptide KiSS-1. Journal of Biological Chemistry 2001276 28969-28975.

4 Kotani M, Detheux M, Vandenbogaerde A, Communi D, Vanderwinden JM, Le Poul E, Brezillon S, Tyldesley R, SuarezHuerta N, Vandeputt F, Blanpain C, Schiffmann SN, Vassart G \& Parmentier M. The metastasis suppressor gene KiSS-1 encodes kisspeptins, the natural ligands of the orphan $\mathrm{G}$ protein-coupled receptor GPR54. Journal of Biological Chemistry 2001276 34631-34636.

5 Lee JH \& Welch DR. Suppression of metastasis in human breast carcinoma Mda-MB-435 cells after transfection with the metastasis suppressor gene, KiSS-1. Cancer Research $1997 \mathbf{5 7}$ 2384-2387.

6 Lee DK, Nguyen T, O'Neill GP, Cheng R, Liu Y, Howard AD, Coulombe N, Tan CP, Tang-Nguyen AT, George SR \& O'Dowd BF. Discovery of a receptor related to the galanin receptors. FEBS Letters $1999 \mathbf{4 4 6} 103-107$.

7 Murphy KG. Kisspeptins: regulators of metastasis and the hypothalamic-pituitary-gonadal axis. Journal of Neuroendocrinology 200517 519-525.

8 de Roux N, Genin E, Carel J-C, Matsuda F, Chaussain J-L \& Milgrom E. Hypogonadotropic hypogonadism due to loss of function of the KiSS-1 derived peptide receptor GPR54. PNAS $2003 \mathbf{1 0 0}$ 10972-10976.

9 Seminara SB, Messager SM, Chatzidaki EE, Thresher RR, Acierno JS Jr, Shagoury JK, Bo-Abbas Y, Kuohung W, Schwin of K, Hendrick AG, Zahn D, Dixon J, Kaiser UB, Slaugenhaupt SA, Gusella JF, O'Rahilly S, Carlton MBL, Crowley WF Jr, Aparicio AJR \& Colledge WH. The GPR 54 gene as a regulator of puberty. New England Journal of Medicine 2003349 1614-1627.
10 Witchel SF \& Plant TM. Puberty: gonadarche and adrenarche. In Yen and Jaffe's Reproductive Endocrinology, 5th edn, ch. 17, pp 493-535. Eds JF Strauss III \& RL Barbieri, Philadelphia, PA: Elsevier, Inc., 2004.

11 Plant TM \& Witchel S. Puberty in non-human primates and humans. In Knobil and Neill's Physiology of Reproduction, 3rd edn, vol. 2, ch. 40, pp 2177-2230. Eds JRG Challis, DM de Kretser, JD Neill, DW Pfaff, TM Plant, JS Richards \& PM Wassarman, San Diego: Elsevier, 2006.

12 Plant TM \& Barker-Gibb ML. Neurobiological mechanisms of puberty in higher primates. Human Reproduction Update 200410 $1-11$.

13 Fraser MO, Pohl CR \& Plant TM. The hypogonadotropic state of the prepubertal male rhesus monkey (Macaca mulatta) is not associated with a decrease in hypothalamic gonadotropinreleasing hormone content. Biology of Reproduction $1989 \mathbf{4 0}$ 972-980.

14 Vician L, Adams LA, Clifton DK \& Steiner RA. Pubertal changes in pro-opiomelanocortin and gonadotropin-releasing hormone gene expression in the brain of the male monkey. Molecular and Cellular Neurosciences 19912 31-38.

15 Ma YJ, Costa ME \& Ojeda SR. Developmental expression of the genes encoding transforming growth factor alpha and its receptor in the hypothalamus of female rhesus macaques. Neuroendocrinology $199460346-359$.

16 El Majdoubi M, Sahu A, Ramaswamy S \& Plant TM. Neuropeptide Y: a hypothalamic brake restraining the onset of puberty in primates. PNAS 200097 6179-6184.

17 Gay VL \& Plant TM. Sustained intermittent release of gonadotropin-releasing hormone in the prepubertal male rhesus monkey induced by N-methyl-DL-aspartic acid. Neuroendocrinology 1988 48 147-152.

18 Plant TM, Gay VL, Marshall GR \& Arslan M. Puberty in monkeys is triggered by chemical stimulation of the hypothalamus. PNAS $1989862506-2510$.

19 Suter KJ, Pohl CR \& Plant TM. The pattern and tempo of the pubertal reaugmentation of open-loop pulsatile gonadotropinreleasing hormone release assessed indirectly in the male rhesus monkey (Macaca mulatta). Endocrinology 1998139 2774-2783.

20 Wray S. Development of gonadotropin-releasing hormone-1 neurons. Frontiers in Neuroendocrinology 200223 292-316.

21 Pescovitz $\mathrm{OH}$. Ontogeny of GnRH neuron function-integration. In The Onset of Puberty in Perspective, pp 37-38. Eds J-P Bourguignon \& TM Plant, Amsterdam, The Netherlands: Elsevier Science, 2000.

22 Goldsmith PC, Thind KK, Song T, Kim EJ \& Boggan JE. Location of the neuroendocrine gonadotropin-releasing hormone neurons in the monkey hypothalamus by retrograde tracing and immunostaining. Journal of Neuroendocrinology 19902 157-168.

23 Shahab M, Mastronardi C, Seminara SB, Crowley WF, Ojeda SR \& Plant TM. Increased hypothalamic GPR 54 signaling: a potential mechanism for initiation of puberty in primates. PNAS $2005 \mathbf{1 0 2}$ 2129-2134.

24 Smith JT, Clifton DK \& Steiner RA. Regulation of the neuroendocrine reproductive axis by kisspeptin-GPR 54 signaling. Reproduction $2006131623-630$.

25 Plant TM, Ramaswamy S \& DiPietro MJ. Repetitive activation of hypothalamic $\mathrm{G}$ protein-coupled receptor 54 with intravenous pulses of kisspeptin in the juvenile monkey (Macaca mulatta) elicits a sustained train of gonadotropin-releasing hormone discharges. Endocrinology 2006147 1007-1013.

26 Irwig MS, Fraley GS, Smith JT, Acohido BV, Popa SM, Cunningham MJ, Gottsch ML, Clifton DK \& Steiner RA. Kisspeptin activation of gonadotropin releasing hormone neurons and regulation of KiSS1 mRNA in the male rat. Neuroendocrinology $200480264-272$.

27 Shibata M, Gibbs RB, Shahab M \& Plant TM. GnRH neurons in the peripubertal male rhesus monkey (Macaca mulatta) express GPR 54: implication for the control of primate puberty. 87th Annual Meeting of The Endocrine Society, San Diego, 2005 (Abstract P1-98). 
28 Plant TM. The male monkey as a model for the study of the neurobiology of puberty onset in man. Molecular and Cellular Endocrinology [Epub ahead of print].

29 DiPietro MJ, Ramaswamy S, Seminara SB, Crowley WF Jr \& Plant TM. Attempts to activate a pubertal pattern of $\mathrm{GnRH}$ release in juvenile male rhesus monkeys (Macaca mulatta) with continuous low dose infusions of human metastin 45-54. 6th International Congress of Neuroendocrinology, Pittsburgh, 2006.

30 Seminara SB, DiPietro MJ, Ramaswamy S, Crowley WF Jr \& Plant TM. Continuous human metastin 45-54 infusion desensitizes GPR54-induced GnRH release monitored indirectly in the juvenile male rhesus monkey (Macaca mulatta): a finding with therapeutic implications. Endocrinology $20061472122-2126$.

31 Semple RK, Achermann JC, Ellery J, Farooqi IS, Karet FE, Stanhope RG, O'Rahilly S \& Aparicio SA. Two novel missense mutations in G protein-coupled receptor 54 in a patient with hypogonadotropic hypogonadism. Journal of Clinical Endocrinology and Metabolism 200590 1849-1855.

32 Messager S, Chatzidaki EE, Ma D, Hendrick AG, Zahn D, Dixon J, Thresher RR, Malinge I, Lomet D, Carlton MBL, Colledge WH, Caraty A \& Aparicio AJR. Kisspeptin directly stimulates gonadotropin-releasing hormone release via $\mathrm{G}$ protein-coupled receptor 54. PNAS $2005 \mathbf{1 0 2} 1761-1766$.

33 Han S-K, Gottsch ML, Lee KJ, Popa SM, Smith JT, Jakawich SK, Clifton DK, Steiner RA \& Herbison AE. Activation of gonadotropinreleasing hormone neurons by kisspeptin as a neuroendocrine switch for the onset of puberty. Journal of Neuroscience 200525 11339-11356.

34 Navarro VM, Fernández-Fernández R, Castellano JM, Roa J, Mayen A, Barriero ML, Gaytan F, Aguilar E, Pinilla L, Dieguez C \& TenaSempere M. Advanced vaginal opening and precocious activation of the reproductive axis by KiSS-1 peptide, the endogenous ligand of GPR54. Journal of Physiology 20042 379-386.

35 Dhillo WS, Chaudhri OB, Patterson M, Thompson EL, Murphy KG, Badman MK, McGowan BM, Amber V, Patel S, Ghatei MA \& Bloom SR. Kisspeptin-54 stimulates the hypothalamic-pituitary gonadal axis in human males. Journal of Clinical Endocrinology and Metabolism $2005906609-6615$.

Received 28 April 2006

Accepted 21 June 2006 